\title{
«КАМІННИЙ ГІСТЬ» О. ПУШКІНА І «КАМІННИЙ ГОСПОДАР» ЛЕСІ УКРАЇНКИ У КОНТЕКСТІ СВІТОВОЇ ТЕМИ: ДО ПРОБЛЕМИ ТРАДИЦІЙНОГО МОТИВУ В ЛІТЕРАТУРІ
}

У статті автор шляхом несинхронного зіставлення аналізує поетичні драми «Камінний гість» Олександра Пушкіна $і$ «Камінний господар» Лесі Українки в контексті світової теми про Дон Жуана, акцентуючи увагу на контактноісторичних зв'язках літератур.

Ключові слова: образ, сюжет, мотив, традиційний, інтерпретаиія, алюзія, ремінісиенція.

В статье автор путем несинхронного сопоставления анализирует поэтические драмы «Каменный гость» Александра Пушкина и «Каменный хозяин» Леси Украинки в контексте мировой темы о Дон Жуане, акцентируя внимание на контактно-исторических связях литератур.

Ключевые слова: образ, сюжет, мотив, традичионный, интепритачия, аллюзия, реминисценция.

In this article the author analyses the poetic dramas «Kamminyi hist'》 written by O. Pushkin and «Kamminyi gospodar» by Lesia Ukrainka using a non-synchronous comparison in the context of world subject about Don Juan and accents the attention on the contact-historic ties of the literatures.

Key words: image, plot, motive, traditional, interpretation, allusion, reminiscence.

Традиційні образи, сюжети, мотиви виникають, як правило, здебільшого в національних фольклорах, історіях, літературах. Багато з них переходять до інших літератур, набуваючи при цьому різних самобутніх оновлень та інтерпретацій на інонаціональних грунтах.

Найпоширенішими 3 них є античні, біблійні, середньовічні образи та мотиви, які часто називають світовими. 
Упродовж віків вони матимуть різну ідейно-художню трактовку, часто полярну, виступатимуть носіями відповідних світоглядів певної доби, імпульсами суспільних алюзій і літературних ремінісценцій.

Серед відомих традиційних образів, почерпнутих із фольклору та історії (Прометея, Фауста, Отелло, короля Ліра, орлеанської діви Жанни, Ходжі Насреддіна тощо), одним із найпоширеніших у літературі на протязі кількох віків (XVI-XX ст.) є образ Дон Жуана (Хуана, Гуана, Джованні тощо) - спокусника жінок, не гребуючого для цього ніякими гріховними переступами, богохульника, носія блудного начала як імпульсу до будь-якого злочину заради досягнення амурних перемог, що в підсумку закінчаться черговими зрадами спокушених жертв.

Першим у літературі до цього відомого фольклорного персонажа звернувся іспанський драматург Тірсо де Моліна (приблизно 1570-ті - 1648 роки життя) у філософсько-релігійній драмі барокового плану «Севільський дурисвіт, або Камінний гість». У творі не тільки розвінчується придворний фаворитизм як одна 3 причин безкарності розбещених аристократів. Тут властивий насамперед осуд людини за їі земні вчинки, гріхи перед Богом, перед яким мусить дати звіт, і вина перед суспільством елітарних прошарків, вищих каст, що жили по суті за аморальними принципами. Син придворного фаворита Дон Гуан із п’єси Тірсо де Моліна розбещений тривалою безкарністю, вважаючи разом з тим, що в нього вистачить часу, щоб у майбутньому замолити гріхи перед Богом i перед людьми. Своїми вчинками розпусник кидає виклик Богу, i тому поява запрошеної камінної статуї, що карає богохульника, сприймається у драмі як Вищий Суд над відступником від земних $і$ небесних законів. Так у творі драматурга інтерпретується відома фольклорна фабула про вчинену розплату над грішником Камінним Гостем, виступаючим власне караючим мечем.

Сам король на вимогу зганьблених і скривджених людей змушений був засудити придворного улюбленця: кривдника судять і Небо, і суспільні моральні закони. Так автор п’єси намага- 
ється розв'язати дві ключові проблеми драми - релігійно-філософську і суспільно-моральну.

Після першої спроби художнього осмислення відомого фольклорного мотиву до теми Дон Жуана звертатимуться немало митців. Серед них зустрічатимуться літературні версії Ж.-Б. Мольєра, К. Гольдоні, Е. Т. А. Гофмана, С. Річардсона, Дж. Байрона, О. Пушкіна, Жорж Санд, П. Меріме, О. К. Толстого, Лесі Українки, Бернарда Шоу, С. Черкасенка тощо, музичні інтерпретації В. А. Моцарта, О. Даргомижського, Й. Штрауса та ін.

Національно-традиційний тип розпусника з іспанської версії ченця Тірсо де Моліни швидко переходив в інші літератури. Відомо немало різних переробок твору в Італії, Франції, які дещо спрощують теологічно-філософський погляд на проблему в стилі ренесансних ідей свободи особистості, у наділенні одіозної постаті комічно-жартівливими елементами, іронічно-зневажливим колоритом, підкреслено богоборчими рисами: барокові настрої релігійно-філософського трактування традиційних образів і сюжетів поступались класицистичній естетиці з їі пріоритетами розуму, морального дидактизму, виразною соціальною спрямованістю. Так по-своєму був трактований згідно з класицистичними принципами образ спокусника і богохульника в комедії Мольєра «Дон Жуан, або Камінний гість» - власне в кращій французькій версії світової теми.

П’єса, у якій мало комічного (по суті це серйозна комедія соціального плану), має передусім і класове спрямування в трактовці добра і зла: адже цинік, пройдисвіт, гвалтівник, відвертий богохульник Дон Жуан є дворянином, аристократом. Саме ця кастова привілейованість дає можливість нахабно чинити будь-які переступи, спонуковувані егоїстичними інстинктами розпусника та певною мірою ліберальними тенденціями філософії ренесансу з іiі підкресленою увагою до розкріпачення свобод і прав.

Комедія Мольєра була написана в 1664 році і вперше поставлена через рік. Це твір, у якому драматург дещо відступає від принципів класицизму: герої п’єси не є однозначними у своїй тра- 
ктовці, не зберігається єдність трьох факторів (дія, місце, час), комічне часто поєднується 3 трагічним.

Сам мольєрівський Дон Жуан є розпусником і циніком без докорів совісті, оскільки його соціальний статус аристократа 3 привілейованістю на вседозволеність виправдовує в його розумінні будь-яку богопротивну мораль, зневагу до церкви і Бога. Він брутально поводиться зі своєю колись підступно звабленою Ельвірою, котру викрав із монастиря (власне спокушена жінка застерігає його небесною карою), образ якої вчергове затьмарюється іншими жінками, одночасно залицяється до двох вродливих селянок Шарлотти і Матюріни, бездушно, як невдячний син, поводиться 3 власним батьком доном Луїсом. Правда, мольєрівський Дон Жуан разом $з$ тим не позбавлений і лицарської честі, про що говорить безкорисливий порятунок ним дона Карлоса (а саме останній мав помститися розпусникові за зганьблену честь сестри). Саме такий нюанс у поведінці головного персонажа мав підкреслити загальноприйняті принципи моральних засад аристократичного суспільного прошарку, який при всіх показних і декларованих чеснотах проявляв уседозволеність, егоїзм і зневагу до всього сущого. Проте серцевиною мольєрівської п'єси є зіткнення двох начал - аристократичної вільної моралі вседозволеності та безкарності з буржуазною показною добропорядністю, з нарочитою релігійністю, що потім у реальних вчинках виявляється звичайним лицемірством, фальшивою набожністю. Носієм першого начала виступає дворянин-розпусник Дон Жуан, другого - його слуга Сганарель. Дон Жуан зневажає християнську мораль, церкву і Бога, демонструючи свою хулу і на Творця, і на Заповіді, i на найсвятіші принципи. Своїм лицемірством і брехливістю для досягнення власних цілей він несе в собі щось і від іншого мольєрівського героя святенника і водночас циніка Тартюфа. Однак не набагато кращим від свого пана є слуга Сганарель, котрий на словах захищає церкву, мораль, релігійні норми, а насправді є боягузливим лицеміром, який любить понад усе гроші. 
Трагікомічним є фінал п’єси, де нерозкаяний Дон Жуан провалюється в пекло, зіштовхнутий туди статуєю убитого ним Командора, а Сганарель вражений тим, що його пан не встиг сплатити належних своєму слузі грошей. Така розв'язка визначає моральну суть двох, здавалось би, полярних начал - боговідступничого вільнодумства і фарисейського святенництва.

Характерно, що навіть розіграна Дон Жуаном роль розкаяного блудного сина перед батьком доном Луїсом насправді виявиться лицемірством і фальшю.

Донжуанівські мотиви набувають дещо іншої інтерпретації в дусі морального дидактизму в часи Просвітництва, зокрема у відомому сентиментальному романі С. Річардсона «Клариса Харлоу» («Клариса, або Історія юної леді» - 1748 р.).

Власне в образі спокусника Ловеласа тут простежується певною мірою реалістична версія традиційного героя, який водночас може поєднувати в собі різні риси - і позитивні, і негативні. Він може бути і чесним, і мерзотним, i легковажним, і не позбавленим здорового глузду, i нестримним у досягненні мети, i шляхетним, $\mathrm{i}$ огидним, i врешті-решт здатним до великодушності, до покаяння перед смертю: егоїстичний та аморальний спокусник доброчесної Клариси, діставши заслужену покару від іiі брата на дуелі, помирає 3 іменем дівчини на устах. За визначенням Д. Дідро, це «негідник, якого любиш, яким захоплюєшся, якого зневажаєш, який завжди дивує вас, у якій би подобі не з'явився».

Самобутнє осмислення світової теми через сприйняття відомої опери Моцарта (через музичне втілення геніальним композитором і донжуанівського, i фаустівського сюжетів) подає в романтично-трагедійному стилі Е. Т. А. Гофман у новелі «Дон Жуан» («Нечуваний випадок, що трапився з якимось мандрівним ентузіастом» - 1812) - містично-філософському творі, де головний герой «мандрівник-ентузіаст», глибоко трагічно сприймаючи зміст моцартівського творіння, зазнає якогось внутрішнього єднання з виконавицею ролі дони Анни: артистка настільки входить у життя 
своєї героїні, що через дві години після закінчення спектаклю вночі помирає. Саме цю трагедію містично відчуває в той же час ентузіаст, котрий зумів зрозуміти основну ідею геніального Моцартового твору: прагнення до вищого, неземного ідеалу жінки приводить Дон Жуана в тенета диявола. Спокусник мефістофельської вдачі, розпаливши пристрасть у душі Анни (він є убивцею їі батька Командора), мусить загинути разом зі своїм знайденим ідеалом кохання.

Власне актриса, яка в грі пережила ту любов-пристрасть, теж гине. А герой-мандрівник через цю земну трагедію, через ії містичне сприйняття приходить до думки, що тільки в смерті відкривається справжня сила кохання.

Тяжіння до містичного сприйняття дійсності характерне для багатьох романтиків. Властивою стає для декого 3 них підвладність демонічній стихії, яка в апологетиці свободи особистості продукувала ідеалізацію і реабілітацію того, що не сприймалось традиційною мораллю. Слушно зазначає з цього приводу (мається на увазі схильність до демонізму у творчості ряду класиків романтичної доби: міфологізація дійсності часто йшла поряд із демонізацією) один із православних мислителів: «Однако в истории мировой культуры романтизм стал очередным, малозаметным шагом, уводящим человеческое мировое восприятие по дороге от Бога... Он "развивал чувствительность", "воспитьвал добрые нравы",, "учил сострадать несчастным"... Все эти "высокие" чувства оказались магическими кругами, которые не спасают от ада» [Воробьевский 2005: 54].

Геніальний Гете, наприклад, облагородив і прикрасив Мефістофеля, задум якого нібито утверджував сам Бог. Реабілітація та ідеалізація сил тьми художньо вмотивовується в багатьох романтиків.

Не позбавлений цього і романтичний скептицизм, який поєднується з бунтівним духом і відчаєм водночас, великого англійського поета і суспільного діяча Дж. Г. Н. Байрона (другу іпостась класик вважав головною у своєму житті, борючись за свободу Італії, 
Греції, народів, які потерпали від поневолення турками). Бунт проти Бога, намагання разом 3 тим стати і над духами зла $з$ метою самоствердження, яке однак не приносить ні спокою, ні щастя, визначають ідейний зміст містерій «Манфред», «Каїн». По-своєму підходить Байрон до традиційного образу Дон Жуана в однойменному віршованому романі, над яким працював протягом кількох років (1817-1823).

Ідеалізація образу Дон Жуана в байронівському скептицизмі переходить тут у пародіювання, згодом у сатиричне зображення дійсності, фальшивої моралі, суспільних і особистих відносин. Байронівський герой привабливий чесністю, внутрішнім благородством, чистотою мрій, пошуками великого кохання, жіночого ідеалу. Але він позбавлений волі опиратися пристрастям, тим паче, що загальновизнаної моралі не визнає. Відрізняються від мольєрівської Ельвіри і гофманівської Анни й коханки байронівського героя. Дон Жуан власне любить по-справжньому і Джулію, і Гайде, і врятовану під час облоги Ізмаїлу туркеню, і Аврору. Особливо вражають стосунки Дон Жуана і доньки пірата Гайде, трагізм їхнього справді самовідданого кохання, яке і руйнується всупереч мріям героя.

Пізнаючи жорстокості світу, байронівський Жуан поступово позбавляється романтичних ілюзій, усвідомлює суворість життєвих реалій, немилосердність дійсності: так перемагає у творі авторський скептицизм, іронізування не тільки над долею героя, а й своєю власною, сам персонаж цього по суті сатиричного віршованого епосу відтворений у процесі виховання життям, у пошуках ідеалу. Нагадаємо, жодну з жінок байронівський персонаж не зраджує - любовні стосунки руйнуються самими обставинами. I в цьому теж убачається іронія над романтичною окриленістю як автора, так і його героя.

Концепцію розкаяного грішника в образі Дон Жуана де Маранья подає в новелі «Душі чистилища» П. Меріме. Його персонаж, кидаючи виклик Богові, намагається викрасти черницю 3 монастиря, але... потрапляє у видінні на власний похорон: труну 
несуть «душі чистилища», визволені материнською молитвою. Розкаяний грішник Дон Жуан де Маранья іде після цього в монастир, хоча гріх його подвоюється: захищаючись, убиває брата зведеної колись дівчини. Чернечий аскетизм, життя в молитвах і спокуті рятують грішника, який вмирає у святості.

Самобутню, докорінно відмінну від попередніх, версію традиційного образу подає в 1830 році (в «болдинську осінь») російський поет Олександр Пушкін в одній із «маленьких трагедій» «Каменный гость», де герой широко розповсюдженої легенди, інтерпретованої багатьма літераторами, уперше постає як персонаж глибоко трагічний i в неординарності характеру, i в пошуках ідеалу кохання. Великий російський поет в ідейно-художньому змісті драми втілює певною мірою й автобіографічні алюзї, власне мрії, неспівмірні з дійсністю. Як і Байрон, і Гофман, Пушкін відштовхується від традиційного трактування легендарного персонажа, намагається реабілітувати його, зобразити трагізм героя, який, спокушаючись життєвими пристрастями, урешті знаходить справжнє кохання, але гине внаслідок відплати за минулі гріхи, так і не здобувши омріяного щастя.

Байрон 3 властивим йому скептицизмом виводить свого Дон Жуана з романтичних ілюзій до життєвих реалій, Гофман надає своєму персонажу, стилізуючи суб’єктивно зміст Моцартового творіння, ореолу містичної фатальності.

Реабілітуючи традиційного героя, Пушкін іде іншим шляхом. Його твір - це свого роду аналіз пристрасті, долі людини, яка головний зміст життя вбачає в пошуках жіночого ідеалу.

Пушкінський Гуан ніжний, поетичний, щирий і безкорисливий у своїх почуттях. Йому не властиві жорстокість та бездушність, грубість та егоїзм класичних попередників. У той же час Дон Гуан із «маленькой трагедии» є сміливою, рішучою людиною, не позбавленою благородств і лицарських чеснот. При всьому тому він талановита, творча особистість: саме пісню на його слова виконує Лаура. У своїх почуттях до жінок (у пушкінській драмі ми 
зустрічаємо двох наяву - Анну і Лауру, і третю в спогадах - Інезу) він позбавлений лукавства і зрадливості. Пушкінський Гуан не $є$ розпусником і професійним мерзотником-відступником.

Його захоплення цілком щирі: у даному випадку тут властива віра в те, що все всерйоз і назавжди, навіть такі легкі, жартівливо веселі любовні зв'язки з вільнолюбною у виборі актрисою Лаурою.

Урешті пушкінський герой по-своєму й моральний, хоча ця мораль відповідає скоріше гуманістичним, а не християнським принципам: власне це індивідуальність, залюблена в земне життя, тому й постійно невдоволена в пошуках того ж таки земного ідеалу, котрий часто виявляється примарним.

Однак і втрачених жінок, часто з його ж вини, Гуан згадує 3 ніжністю і співчуттям.

Про погублену Інезу він, наприклад, говорить із сумом як про жертву кохання, нещасливу в шлюбі 3 нелюбим чоловіком («...голос У ней был тих и слаб - как у больной - Муж у нее был негодяй суровый, Узнал я поздно... Бедная Инеза!» - 3, 129) і як про оманливий ідеал («Tbl кажется ее не находил Красавицей. И точно, мало было В ней истинно прекрасного. Глаза, Одни глаза. Да взгляд... такого взгляда Уж никогда не встречал»-129). Дон Гуан упевнений у власній шляхетності і популярності, навіть у симпатіях до себе самого короля:
Меня он удалил, меня ж любя;
Чтобы меня оставила в покое
Семья убитого... [Пушкин 1968: 128].

Герой постає перед нами тоді, коли починає усвідомлювати, що всі попередні захоплення були звичайним обманом його поетичної уяви, артистичного екстазу:

\section{Они сначала нравилися мне \\ Глазами синими да белизною}




\begin{abstract}
Да скромностью - а пуще новизною;
Да, слава Богу, скоро догадался-

Увидел я, что с ними грех и знаться -

В них жсизни нет, все кукль восковые
\end{abstract}

[Пушкин 1968: 128].

Власне пушкінський Гуан зображений на початку трагедії в момент гіркого розчарування, що незабаром зміниться відчуттям знайденого щастя, а це визначить трагічну ситуацію: герой зустрічає неждано-негадано справжнє кохання - Дону Анну, яка носить жалобу за своїм мужем (саме його вбивцею і є Дон Гуан: на відміну від попередників Пушкін зображує Анну не донькою, а вдовою Командора, що і підсилює психологічну любовну колізію).

Вигнанець Дон Гуан з'являється в Мадриді, щоб зустрітись iз юною куртизанкою, артисткою Лаурою. Пушкін тут вводить новий образ - такого собі морального двійника Гуана в жіночій подобі, щоб поглибити характер героя, легковажного в любовних пригодах і трагічного водночас у своєму коханні до Анни, коханні, котре поставило б на шлях прозріння і покаяння.

Зустріч з Лаурою була, однак, затьмарена черговим переступом: заставши в коханки Дона Карлоса, Гуан на поєдинку убиває суперника і без тіні сумління залишається в куртизанки. Власне це було тоді, коли тривогу, що переросте незабаром у вбивчу пристрасть, у серці героя запалив образ іншої жінки, поміченої випадково в скорботі біля статуї Командора («Под этим вдовьим черным покрывалом чуть узенькую пятку я заметил» [Пушкин 1968: 133].

Новим мотивом у пушкінській драмі $є$ і переодягання Дон Гуана монахом. Це шлях до знайомства 3 жінкою в жалобі, яка скоріше $є$ традиційно показною, ніж внутрішньою потребою, оскільки Анна ніколи не кохала чоловіка: їі примусили вийти заміж з розрахунку («Мы были бедныл, Дон Альвар богат» [Пушкин 1968: 133].

Колізія поглиблюється тим, що Дона Анна відгукується на почуття Дона Дієго (таким ім'ям називався їй Гуан), і це цілком 
психологічно вмотивовано: адже вона ніколи не спізнала в душі справжньої любові.

Проте Дон Гуан не тільки прагне перевірити почуття Анни, а й хоче бути чесним перед нею. Саме тому і відкриває ій правду про смерть чоловіка: адже жінка клялася помститися вбивці («Тогда бы я злодею Кинжал вонзила в сердиее» [Пушкин 1968: 159]).

Гуан чекає присуду! Однак Анна не в силі опиратися своїм почуттям («О Дон Гуан, как серцем я слаба» [Пушкин 1968: 159]).

Сцена зізнання $є$ кульмінаційною в драмі. Вона $є$ свідченням того, що герой, знайшовши нарешті свій ідеал, близький до покаяння і виправлення. Він прагне заручитися надією і прощенням у знайденої так неждано любові. Однак Гуана знаходить і неждана розплата: здійснені в минулому тяжкі гріхи не відпускають його.

Тим паче, що пушкінський персонаж завжди покладався на свою волю, ігноруючи волю Творця. Цим він і схожий на своїх класичних попередників, саме як цинік і безбожник. Адже запрошення статуї убитого Командора в гості під час любовного побачення 3 дружиною покійника було не тільки невинним жартом, а й свого роду святотатством.

Звідси і трагічні наслідки. Поєднання з Анною, яка відповіла на почуття, подала надію на наступну зустріч, що визначила б подальшу долю обох, виявилось неможливим.

Адже їм двом, і Гуану, і Анні (кожному по-своєму!), доведеться відповісти за свої гріхи. Статуя Командора, яка визначить трагічний фінал, виступає тут символом гріховного минулого, яке стає перепоною до його омріяного, знайденого, але так і не здобутого героєм щастя.

У цьому полягає і головна ідея геніальної пушкінської трагедії, що згодом трансформується в трагедію самого автора.

Подібно до свого героя Пушкін пережив немало захоплень, любовних колізій, які часто завершувались розчаруваннями, дуелями, і власне писав свого «Камінного гостя» тоді, коли надіявся знайти свій жіночий ідеал, вимріяну Мадонну в образі Наталі Гон- 
чарової, справжню незгасаючу любов. Зустріч Гуана 3 камінним гостем як символом караючої долі - це якесь прозірливе передчуття поетом власного трагічного кінця. На творчому злеті, на стезі до духовно-морального очищення цей кінець принесе російському генію куля чужинця - кавалергарда Жоржа Дантеса, своєрідний прообраз якого зумів інтуїтивно відчути поет у караючій Статуї. Існує версія, що хтось із гадалок застерігав Пушкіна про фатальну небезпеку від білого чоловіка на білому коні: справді білявий убивця Дантес носив білий мундир і їздив на білому коні.

Так у знамениту болдинську осінь великий поет у долі геніально інтерпретованого ним самим Дона Гуана зумів відчути свою власну.

Романтичні інтерпретації образу класичного героя в дусі навернення його до покаяння й очищення залишили іспанський поет Зорілья (п’єса «Дон Жуан Теноріо» - 1844) і російський майстер поетичної драми О. К. Толстой (драматична поема «Дон Жуан» - 1860).

Власна самобутня ідейно-художня інтерпретація традиційної світової теми, до якої зверталось протягом століть багато класиків, була здійснена Лесею Українкою в драмі «Камінний господар» (1912) - творі, який може 3 повним правом вважатися одним iз кращих здобутків української, а також європейської модерної драми початку XX ст. Драма поетеси є українською версією світового мотиву, визначаючи актуальні проблеми своєї доби (екзотичні образи та мотиви - античні, біблійні, середньовічні тощо - письменниці є своєрідною метафорою національного життя), будучи при цьому і прозірливим застереженням, вносячи у відому світову фабулу новітні ідейно-філософські і психологічні акценти.

Незаперечним тут є передусім і історико-генетичний зв'язок з пушкінською версією, яка стала своєрідним імпульсом для створення поетесою власного шедевру із самобутнім трактуванням (враховуючи досвід мистецьких поколінь) відомих образів, з осмисленням ідейних теорій свого часу - ілюзорних та оманливих. Пушкінська драма «Камінний гість» була в руках Лесі Українки (поетеса в цей час лікувалась у м. Хоні на Кавказі), коли вона працю- 
вала над «Камінним господарем» - твором, у який було вкладено відмінне від російського попередника трактування образів камінної статуї, Дон Жуана та Анни, введені інші персонажі (тут діє ще живий Командор, зосереджена увага на самовідданості й жертовності, уособленням яких виступає прекрасна Долорес - духовноморальний ідеал самої авторки). Та й звернімо увагу на назви: адже поняття «гість» і «господар» мають протилежні значення. Камінна Статуя в Пушкіна виступає символом гріховного минулого, яке не відпускає Дон Гуана, стає між ним та омріяним щастям, знищує героя фізично на грані морального переродження. Тут Статуя - гість, гість фатальний, що несе заслужену покару.

Леся Українка в «камінність» закладає інше поняття. Воно пов'язане не тільки з образом Командора, з його статусом і місцем у суспільстві. Камінними стають серця і душі людей. А це несе їм постать Командора - уособлення владного, мертвотного, заскорузлого, бездуховного, врешті всього того, що знищує особистість, спокушену гординею, себелюбством, прагненням винищитись над іншими, здобути свободу для себе ціною переступів і зрад. Камінний Мадрид у драмі теж набуває метафоричності. Саме туди рветься Лесин «лицар волі», де навіть «повітря кам'яне», для здобуття примарного щастя, тої «свободи», яка «закам'янить» душу.

Власне в «Камінному господарі» Лесі Українки порушується вперше проблема спокуси... самого класичного спокусника (характерно, що фільм за драмою Лесі Українки так і називався - «Спокуса Дон Жуана»).

Лесеукраїнківський Дон Жуан був спокушений жінкою, одержимою ідеєю влади: певною мірою відчувається тут мотив шекспірівської героїні Леді Макбет як своєрідного імпульсу до відступництва.

У драмі поетеси немає й натяку на якесь моральне очищення «лицаря волі», як це намагались інтерпретувати в епоху романтизму, крім названих уже авторів, Мюссе в поемі «Намуна», О. Дюма в п’єсі «Дон Жуан де Маранья». На початку ХХ ст. з'явилось не- 
мало модернізацій старовинного сюжету з прообразами класичного героя. Це повість «Новий Дон-Жуан» французького письменника Бар'єра (саме тут першою скрипкою виступає не традиційний аристократ-спокусник, а його слуга Сганарель, який міняється 3 господарем ролями: саме його, Сганереля, прекрасно зіграв в екранній версії чудовий актор-комік Фернандель), роман польського модерніста С. Пшибишевського «Ноmo sapiens», драма Бернарда Шоу «Людина і надлюдина» тощо.

Добре будучи обізнаною з історією донжуанівських фабул, Леся Українка осмислила традиційну тему по-своєму, не вдаючись до жодних наслідувань чи осучаснюваних модифікацій.

Безперечно, ідеї, втілені поетесою в неокласичній драмі, несуть самобутній філософський підтекст, співзвучні суспільно-політичним і морально-етичним проблемам доби, звучать застереженнями й прогнозами на майбутнє. 3 усіма іншими творами, присвяченими Дон Жуану, драму Лесі Українки пов'язує лише спільність фабули: в інтерпретації старовинної теми поетеса була цілком незалежною, а пушкінський «Камінний гість», який авторка тримала в руках перед написанням власної версії, був лише імпульсом до самобутнього, неадекватного традиціям, художнього осмислення.

Лесиного Дон Жуана вирізняє насамперед не вміння підкорити жіночі серця, не пристрасть спокусника. Це передусім людина, яка кинула виклик усталеним суспільним принципам, для якої воля понад усе. Герой незалежний від різних умовностей, традиційної моралі, здатний на відчайдушні вчинки, які можуть бути i негідними лицарської честі: для «лицаря волі» властиво добиватись бажаного будь-якою ціною (навіть Командора Жуан убиває підступно, діє в поєдинку далеко не по-лицарськи).

Дон Жуан разом $з$ тим зневажає владу, кар'єру, соціальні блага, оскільки вони обмежують людську свободу. Однак його зустріч $з$ Анною (це пряма протилежність смиренній пушкінській героїні, котра не змогла протистояти своїм почуттям до вбивці чоловіка) - нареченою, а потім дружиною Командора - виявилась 
фатальною: остання любов героя зробила жертвою вже його самого. Апологета свободи спокушає «камінна» влада, і провідником цієї спокуси в його житті стає Дона Анна, що виявилась значно сильнішою за поборника «волі і незалежності». Горда, неприступна і владна жінка, котра виходить за Командора 3 престижних i корисливих міркувань, егоцентрична і себелюбна, зуміла скорити Дон Жуана «камінним щастям», підпорядкувати волю особистості принадам багатства і влади.

Самій Анні в досягненні честолюбної мети після смерті чоловіка Дон Жуан став просто необхідний: тільки така смілива людина, як цей коханець, що міг переступити будь-які закони неба i землі, здатна бути опорою в торуванні шляху до меркантильних $і$ честолюбних ідеалів підступної жінки, одвертої тепер цинічно у своїх намірах. Знаючи, що перстень, який носить Дон Жуан, - це спогади про минулу волю, про людську безкорисливість і самовідданість, втілені в образі Долорес, Анна вимагає од коханця зняти цю реліквію великодушності і порядності, останню ознаку лицарської гідності і честі.

Переступити через чиєсь життя, через найсвятіше Анна вважає одвагою, подвигом, який має здійснити коханець в ім'я влади і благополуччя - «камінного щастя». Перемагає тут справді «камінне», мертвотне. Про свою спокусу зі здивуванням скаже вчорашній «лицар волі»:

Як чудно... лицар волі-переймає

до рук своїх тяжкий таран камінний, щзоб городів $і$ замків добувати...

[Леся Українка 1978: 6, 159].

Попередні розмови героя про лицарські чесноти, про свободу особистості виявились насправді просто позуванням. Внутрішнє підсвідоме бажання мати владу і матеріальні розкоші підкоряє Дон Жуана волі властолюбної й хижої Анни, яка, добре 
розуміючи суть «лицарства» свого обранця, дає оцінку цій показній «волелюбності»:

Доволі вже порожніх слів, Жуане!

Що значить: «лищемірство»? Та ж признайте, щуо ви не все по шүирості чинили, а дещь й вам траплялось «удавати», щуоб звабити чиї прекрасні очі, то відки ж се тепер така сумлінність? Чи, може, тут мета вам зависока?

[Леся Українка 1978: 6, 159].

Мета, виявляється, поєднує тут обох - позірного, здатного до гучної фрази «лицаря волі» (виникає своєрідна асоціація з іншим «поборником свободи» - Лицарем 3 «Осінньої казки» Лесі Українки) й одвертої у своїх честолюбних замірах вдови «камінного» Командора. Спільної мети цих двоє егоцентристів досягають ціною зради найсвятішому - духовно-етичному ідеалу справедливості.

Загибель Жуана й Анни в «Камінному господарі» Лесі Українки (на відміну від пушкінського варіанту легенди) є суто символічною: персонажі стають камінними духовно і морально, гідними спадкоємцями владного Командора. Саме він, зримий і незримий, залишається після фізичної смерті господарем їхніх сердець.

Поетеса в листі до Агатангела Кримського від 6 червня 1912 p. так визначила ідейну суть твору: «...драма (знов-таки драма!) зветься "Камінний господар", бо ідея ї̈-перемога камінного консервативного принципу, втіленого в Командорі, над роздвоєною душею гордої, егоїстичної Донни Анни, а через неї $і$ над ДонЖуаном, "лищарем волі"» [Леся Українка 1978: 12, 396]. Саме така ідейна колізія, втіливши в себе досвід віків, багато в чому виявилась і прозірливим передбаченням-застереженням. Суспільнополітичні реалії трагічного XX століття показали всю облудність багатьох поборників свобод і демократій, що потім нищились сво- 
їми ж ідейно збанкрутілими «провісниками» - носіями (прикметними $є$ слова М. Горького про те, що революції здійснюються для знищення, морального і фізичного, самих же революціонерів). Верховинські і раскольнікови, виписані Ф. Достоєвським, псевдогерої і псевдомесії з творів В. Винниченка 3 теоріями вседозволеності й безбожності виринуть пізніше в іпостасі більшовизму і фашизму.

Лесі Українці, якій, безперечно, імпонували сильні, неординарні особистості, був чужим культ «надлюдини», пропагований ніцшеанством. Розвінчання цих людиноненависницьких теорій лежить в основі полемічної драми поетеси «На полі крові». Ці ж ідеї знайшли логічне продовження і в українському варіанті світової теми - «Камінному господарі». Характерно, що проблему «надлюдини», пропагованої декадентами, апологетами філософії Ніцше (Л. Андрєєв, Д. Мережковський, С. Пшибишевський тощо), порушив англійський драматург ірландського походження Бернард Шоу, написавши п’єсу «Людина і надлюдина» (1903), у якій подав прообраз осучасненого Дон Жуана - Теннера, персонажа парадоксального в основі.

Іронізуючи через образи Теннера та Енн (модернізований варіант Анни) над апологетикою сильної особистості, покликаної завоювати світ, Б. Шоу, однак, не зумів протиставити антилюдяності здорове духовно-моральне начало.

Леся Українка, засуджуючи в образах Дон Жуана й Анни ренегатство і користолюбство, облудній моралі вседозволеності протиставляє ідеал людської жертовності і самовідданості, втілені в образі нареченої «лицаря волі» Долорес, яка успадкувала кращі риси попередніх героїнь поетеси: Міріам з «Одержимої», Анціллодеї із «В катакомбах», Прісцілли із «Руфіна і Прісцілли», Мавки 3 «Лісової пісні». Смислом життя Долорес була ії любов до свого нареченого (заручили їх ще в дитинстві), любов альтруїстична i жертовна, усвідомлена любов без взаємності. Як і Мавка, Долорес здатна в ім'я кохання на самопожертву, на самозречений подвиг. 
Однак, як стверджується в драмі, духовна і моральна вищість, благородство і самовідданість таких жінок у реальному житті не компенсуються перемогою над хижим і меркантильним світом Анни, Командора, над облудністю і позірністю Жуанів. Ціною дівочої честі Долорес звільняє себелюбця Дон Жуана від статусу вигнанця і йде в монастир.

У листі до О. Кобилянської від 3 травня 1913 р. Леся Українка висловила ставлення до героїні як власного морального ідеалу, вважаючи цей образ у драмі навіть біднішим, ніж хотілося б його розкрити, надаючи ідейно-естетичного пріоритету над іншими.

«Шкода мені теж, - зазначала письменниця, - щзо я не вміла поставити Долорес так, щзб вона не здалась блідою супроти Донни Анни, - се не було мойм заміром, $і$ я навіть якийсь час вагалася, хто має бути справжньою героїнею драми - вона чи Донна Анна, і дала перевагу Анні не з симпатії (Долорес ближча моїй душі), а з почуття правди, бо так буває в житті, що такі, як Долорес, мусять відходити в тінь перед Аннами і стають жертвами - властиво не Дон-Жуанів, а власної своєї надлюдської екзальтації. Се тип мучениці природженої, щзо все мусить гинути розп'ята на хресті, хоч би мала себе на той хрест прибити, коли бракує для того катівських рук. Якби не було Дон Жуана, то знайшлось би щуось інше, для чого вона б "душу розп'яла і заколола сериее", бо там, де Анна могла б уже бути щзасливою, Долорес ще б таки не знайшла свого святого грааля, а се тому, щзо над нею нішо "камінне" не має влади...» [Леся Українка 1978: 12, 462].

Образ Долорес, незважаючи на те що письменниця вважала його недостатньо досконалим в ідейно-художньому задумі, не став лише доброю «тінню» головного героя («Се тільки тінь моя»).

Ця героїня Лесі Українки не може не виділятись як яскрава індивідуальність - тип серед інших відомих своєю самовідданістю персонажів з поем і драм поетеси, про які йшла мова вище. У «Камінному господарі» Лесі Українки спостерігаємо цікаву (нововведену в розробку традиційного мотиву) моральну колізію: у боротьбі 
за владу над чоловіком (Жуаном) між двома жінками (Анною і Долорес) перемагає хижа, честолюбна, активна Анна. Перемога хижого, владного, жорстокого й віроломного в душі приводить до фатального кінця обох - і Анни, і Жуана - в духовно-моральному плані.

Смерть героїв у фіналі драми не є фізичною. Адже Командорова постать із дзеркала ніби здійснює завершальний акт поневолення душ: вони поглинаються тьмою. Демонська суть дзеркала тут теж є традиційною метафорою.

Морально вище Анни і Жуана стоїть «забута тінь» - прекрасна у своєму добровільному мучеництві за чужі гріхи Долорес, у якій можемо помітити щось і від героїнь Достоєвського (Соня Мармеладова зі «Злочину і покарання»), і передусім від жінок ібсенівської драматургії: Теї з «Гедди Габлер», Нори з «Лялькового дому», Сольвейг зі знаменитого «Пер-Гюнта». Однак, як слушно зауважується в одному 3 грунтовних досліджень драматургії поетеси, «на відміну від Ібсена, який завжди співчуває могутній духом жінці, трохи зневажливо ставлячись до своїх лагідних, здатних на самопожертву героїнь, Леся Українка всі свої симпатії віддає саме їм.

Вона не тільки «співчуває жінкам - "природженим мученииям", але саме на образи таких жінок переносить дійовий акиент, перетворюючи їх на головних героїнь» [Гозепунд 1947: 226-227].

Саме такий тип самовідданих жінок, здатних на подвиг в ім'я коханої людини, імпонував Лесі Українці. Однак в атмосфері мертвотного, жорстокого, камінного, у суспільстві ситості і продажності, як стверджує поетеса образами Міріам, Анціллодеї, Йоганни, Мавки, жертовні мучениці або гинуть, або змушені нести свій важкий хрест мовчки, не в силі побороти зло власною добротою в земному існуванні. Драма Лесі Українки «Камінний господар» ідейною проблематикою пов'язана не тільки з усією складністю й суперечністю епохи, у яку жила поетеса. Це твір і пророчий значною мірою. 
Це підтвердили і підтверджують трагічні реалії й початку, й середини, й кінця двадцятого віку, і катаклізми сучасної доби. Разом 3 тим ця драма - одна 3 найдовершеніших розробок традиційної світової теми як в ідейно-філософському, так і в художньому планах.

У світлі художніх алюзій і ремінісценцій до класичного образу відомого фольклорного і літературного персонажа звернувся і племінник Лесі Українки Юрій Косач у невеликій прозовій оповіді «Останне втілення командора», у якій легендарний герой лицар Дон Хуан переноситься в іншу епоху, в інші обставини, залишаючись непохитним у пориві до свободи, до несприйняття суспільного середовища. Ремінісценція легенди про великого грішника знайшла самобутнє втілення в художньому задумі I. Франка (поема «Похорон»).

Свою інтерпретацію традиційного образу (покару спокусника за зведення жінок хитрою Розітою) зробив і письменник української діаспори Спиридон Черкасенко в драмі «Іспанський кабальєро Дон Хуан і Розіта» (1931).

Відлуння мотиву світової фабули відчувається і в романах французького класика Гі де Мопассана «Любий друг» й українського письменника, схильного до екзистенційного світобачення, В. Підмогильного «Місто», де подаються модернізовані донжуанівські типи: любовні колізії тут використовуються як фактори кар'єрного сходження.

Проте це вже окрема тема.

\section{БІБЛІОГРАФІЯ}

Воробьевский 2005 - Воробьевский Ю. Русский Голем: Дьяволиада мировой культуры. - Спасо-Преображенский Мгарский монастырь / Ю. Воробьевский. 2005. - 358 c.

Гозенпуд 1947 - Гозенпуд А. Поетичний театр: Драматичні твори Лесі Українки / А. Гозенпуд. - К., 1947. - 302 с.

Леся Українка 1978 - Леся Українка. Твори : у 12 т. - К., 1976-1978. (У тексті зазначаються том і сторінка.)

Пушкин 1968 - Пушкин А. Драматические произведения. - Л., 1968 (Далі посилання в тексті із зазначенням сторінки). -254 с. 